\title{
The Construction of Entrepreneurship Service System of University Students
}

\author{
Min Xie ${ }^{1, a}$, Fanghui $\mathrm{Ju}^{2, \mathrm{~b}}$, ShuQianlv ${ }^{3, \mathrm{c}}$ \\ ${ }^{1}$ Business School, ZheJiang WanLi University, Ningbo, 315100,China \\ 2 Business School, ZheJiang WanLi University, Ningbo, 315100,China \\ ${ }^{3}$ Business School, ZheJiang WanLi University, Ningbo, 315100,China \\ aemail: 41621545@qq.com, bemail: 693478570@ qq.com, 'email: 1158689957@ qq.com
}

Keywords: University students; Entrepreneurship service system; Government; Enterprise

\begin{abstract}
The paper is based on the reality of Ningbo City and according to the business situation of Ningbo students. We takes scientific developmental view as the guide and improves students entrepreneurial effect as the goal .Through field investigation of Ningbo University Students Entrepreneurship, we study on the government, universities, financial institutions, all kinds of the employer, the social from all walks of life to form resultant force .They work together to build a business service system for college students .In order to improve students entrepreneurial success, cultivate the generalized concept of employment, to solve the employment problem, to promote sustainable economic development to provide theoretical guidance.
\end{abstract}

\section{Introduction}

University students entrepreneurship has become a hot topic, which is produced by the expansion of education scale in our country .Our state encourages university students to do poineering work and gives them some preferential policies in some degree .However, we find the environment for college students to do pioneering work is extraordinary difficult .Entrepreneurship and employment is still very difficult for university students. As a result, relaxation of restrictions on students' informal entrepreneurship and the establishment of entrepreneurial service system for university students as soon as possible are should be done by government. Besides hosting stage, local entrepreneurship competition, must try various devices to import the entrepreneurship education .It is especially necessary to liberalise its financial markets, give market a full play to the basic role of market in the allocation of resources and create a loose external conditions for university students' entrepreneurship and employment.

\section{The Current Situation of Entrepreneurship Service System of University students}

With the trend that the higher education in our country is more and more popular, the number of university graduates and employees is growing. The employment condition of university graduate in our country is of increasingly difficulty. In this context, more and more university students choose the way of doing pioneering work by themselves. Entrepreneurship of university students is develop rapidly after the first contest students design held in Qinghua University in 1999, which infused into a new vitality for their entrepreneurial force. As a way for solving employment difficulty and achieving realization, entrepreneurship of college student is also affirmed and encouraged by the government and the social people from all works.

Through the analysis of the university students in Ningbo, the university students in Ningbo have a strong will to do pioneering work. We did a survey in Ningbo University, Ningbo Institute of Technology, Zhejiang University, Zhejiang Wanli University, Ningbo University of Technology, Zhejiang Textile and Fashion College and Ningbo City College of vocational Technology. There are 189 higher vocational students participate in the survey, about 149 students have the will of doing pioneering work, accounting for $79 \%$ of the total. And there are 296 undergraduates participate in the survey, about 179 students have the will of doing pioneering work, accounting for 65\%. 
Although the policy in our country is benefit for students, some practical benefit such as in a venture capital financing is still out of introduction. Venture capitalists tend to social entrepreneurship wait-and-see attitude. While the general knowledge of each big college students entrepreneurial education is just to stay in the primary stage, which is lack pioneering service system of professional training institutions. Compared with some countries in Europe and America, university in our country didn't built an entrepreneurial service system for university students. This mature entrepreneurial service system in Europe and America give them much effective supports .

\section{Restricting factors of Business Service System for University Students}

A. In comparison with other countries, china' s support is not enough

Although Chinese government has put forward some relevant policy to support the students independent venture, but rather late. Compared with some countries in Europe and the United States are still many deficiencies. Entrepreneurship education is popular in the United Kingdom. Results of a survey from the British media. Nearly $30 \%$ of young British idea of their own businesses or are being implemented $53 \%$ of university students wants to be able to become entrepreneurs. To support youth entrepreneurship, the British government put forward a variety of programs and funds. Provide advice and financial, technical, network support for young entrepreneurs though joint business and social forces. More favorable, Mature venture capital and credit system to help students start to solve the funding problem. Then with the developed countries, the united states venture Capital China 's lack of mature capital markets and advisory services. These conditions is the lead university students entrepreneurship and employment for the success of and important factor.

B. Entrepreneurial skills and education efforts in schools is not enough

College is inevitable to take responsibility to develop graduates' entrepreneurship. Nowadays, most of our entrepreneurship education courses' theories lay behind, and can not catch up with the development of 21th century. How to make college students have a reasonable knowledge structure, to equip them with the basic entrepreneurial qualities and abilities, is placed in front of the college and university students a top. On the other hand, entrepreneurial technology is not enough. Colleges and universities as technology-concentrated land. How to gather together and give the technical aspects of direct support and help students start their own business ,is also placed in front of us a top.

C. The lack of credit awareness of University Students

University students' fuzzy cognitive for credit system, is also restricted the development of students to some extent. We can imagine a good credit records of college students in the job will increase the number of intangible capital when searching a job. So how to strengthen the construction of important content of students' credit system is also a part to build a business service system for College Students.

\section{The Construction of Enterprise Service System for University Students}

We recognized that build a university student entrepreneurship service system mainly includes three aspects .First, the construction of school university student entrepreneurship, service system. Second, the construction of entrepreneurship service system. Third, the construction of the government service system. As enterprise ,they should give some support and foster when university student entrepreneurship has some prototype ,like business incubator ,set up the undertaking training class ,display the advantage of local service and to train and guide the entrepreneurship economic and legal .As shown in the fellow figure: 


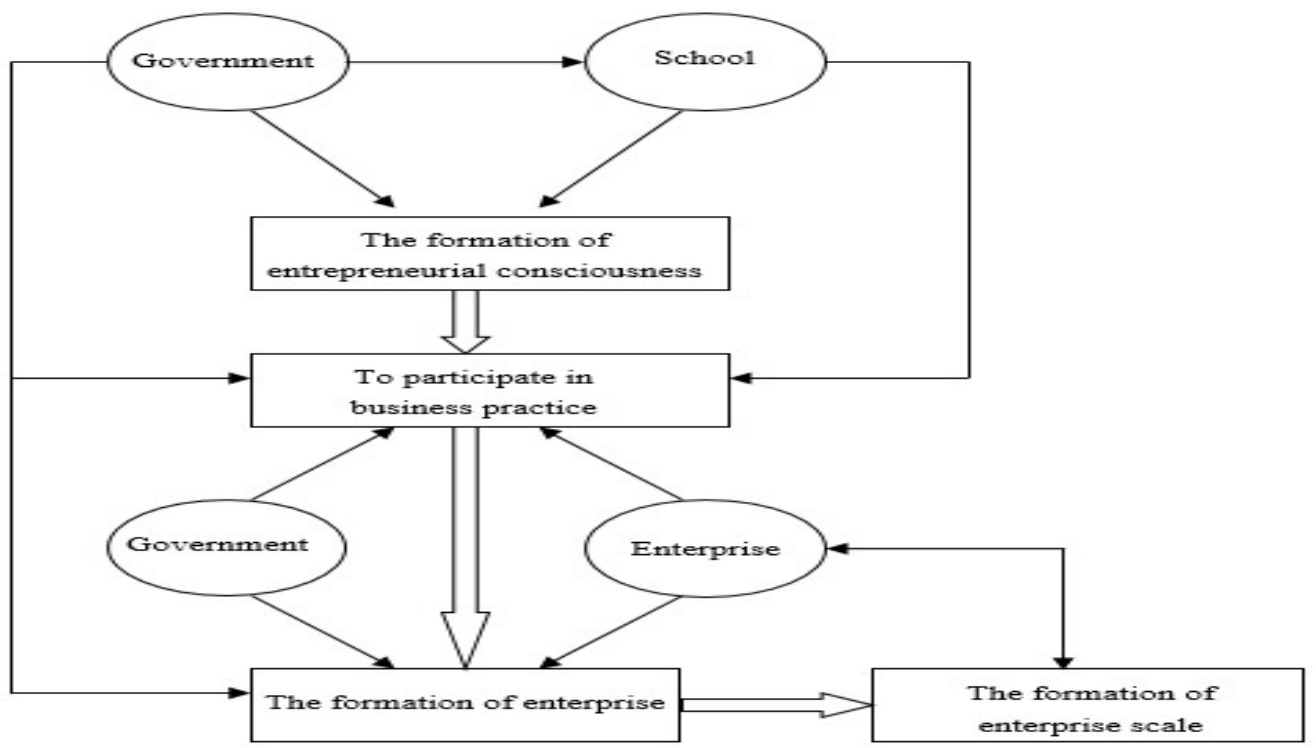

Fig.1.Mode innovation service system for College Student.

\section{A. Cultivation of campus culture}

Campus culture is a university in a mental and physical and chemical characteristic formation in the course of the cultivation of the spirit of long-term talent, including the concept of value in Colleges and universities, history, ethics, code of conduct, the quality of teachers and students and the implication in the image of the campus culture. Entrepreneurial atmosphere of the campus culture means establishing respect for entrepreneurship, entrepreneurial, dare to the spirit of entrepreneurship is needed. For instance, teachers and students in the United States Stanford University were joy from doing pioneering work, which formed a school with a unique entrepreneurial campus culture .It is the reason why the Stanford University continue to the emergence of many famous companies and entrepreneurs, which make the "Silicon Valley" emphasized the global.

B. Actively carry out the business plan competition and encourage students to practice

The Challenge Cup and a business plan competition are a meaningful competition to train students' practical ability ,which can inspire students' entrepreneurship and carry out some good business plan .To give recognition and rewards for those who have outstanding performance in business people.At the same time giving students some preferential policies in the tax and capital, encouraging university students to entrepreneurship .Of course, irregularly lectures given by some outstanding entrepreneurs may influence university students' entrepreneurial thinking and ways of working.

C. Enterprises to participate in the university students' innovative undertaking

Business incubator was first proposed in 1959 and established in the United States, which provides a good information, technology and talent environment in start-ups .Entrepreneurial enterprises only have technique and originality will be a shortage of funds .Even with the support from the early start-up capital ,later enterprise financing will be very difficult .So the incubator plays a very important role in the development process of venture enterprises. Yinzhou youth entrepreneurship incubator park in Ningbo is the only one sponsored by social groups and the social and economic organization of the Incubation Park in Zhejiang Province .It was established to solve capital and site requirements for those mastering high-tech entrepreneurial youth .Science and technology project of young entrepreneurs once approved, you will receive a free office space, as well as by the Bank of Yinzhou, the District Youth Entrepreneurship service center provides financial credit, financial consulting, project declaration, subsidies and a number of business support services.All of these provide a wider selection and strong support for the university students' innovative undertaking .All in all, entrepreneurship through phase needs to enter into the 
incubator for capital, talent support, professional market to guide the project as soon as possible market.

\section{The Operation Security of Entrepreneurship Service System of University Students}

How to make sure the Entrepreneurship Service System of University Students putting into effect? I think the following aspects is needed.

\section{A. Entrepreneurship Service System in School}

In order to exercise and improve the observation ,thinking ability ,imaging ability and operational capacity ,schools should hold various kinds of professional competitions ,scientific research activity ,business design competition and select some applicable achievements .Through improvement, improve, and ultimately moves towards industrialization, it helps build strong scientific and technological innovation in the atmosphere. In our country ,entrepreneurship education is weak .So school should reform the training patterns and sign the education of entrepreneurship into course system .Meanwhile we should set up a team with teachers who have strong creativity ,strong career-ambition and responsibility.

B. The Encouragement and Supporting from government' s policy

In order to protect university students' entrepreneurship ,government can establish a Entrepreneurship Service credit system, which can assess the basic information ,operating and financial reviews, credit position, credit record ,bad record and other credit record .To some enterprise with good credit, government can give them some offset .Meanwhile the enterprise has a better future development with better credit record .Some enterprise even can finance new offices with good credit record .In addition ,government can offer university students with some serve in tax break and advisory.

\section{Support and Recognition from Social}

Many preferential policies are introduced by all parts of the country to encourage university students to start their own businesses. The provinces and cities are actively create the conditions for the university students' innovative undertaking. Enterprises should play a mentoring role to help students getting better business. In addition, holding business exchanges can promote the development of enterprises. The activity named the SYB (start your business) jointly organized by the Ningbo Fande training company and the Ningbo Yinzhou District Committee is a very good support for entrepreneurship policy, which can help university student quickly grasp the business processes and decrease taking a lot of little detour.

\section{Acknowledgement}

In this paper, the research was sponsored by the Department of education of Zhejiang Province (Project No. Y201122016)

\section{References}

[1] GuoGang. The Value Chain and Developing Strategy Research on Chinese Internet Bank-

— Take CMB as an Example. [J]. Pioneering with Science \& Technology Monthly, 2011(8).41-45. [2] LI Bing-lun . On the Construction of Entrepreneurship Service System of University Students. [J].Theory and Practice of Education, 2011(11)14-16.

[3] Fan Kaiju . On the construction of career service system of college students in China. [J]. Journal of Henan Institute of Science and Technology,2012(8)54-60.

[4]Pan Xiao-ping . Exploration and Practice of College Students' Entrepreneurship Education Teaching[J]. Journal of Heilongjiang College of Education,2013(1)55-57. 